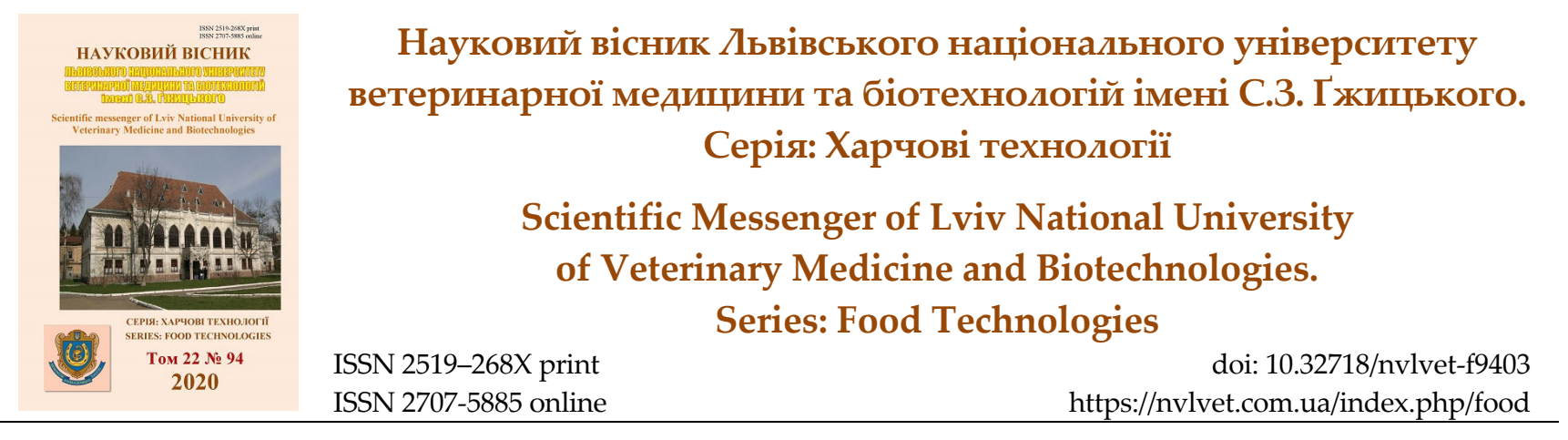

UDC 664.681.9; 664.8.022.7

\title{
The use of sweet potatoes in the technology of cake dough products
}

\author{
A. Boroday, A. Horobes, Y. Levchenko, I. Choni \\ Poltava University of Economics and Trade, Poltava, Ukraine
}

Article info

Received 31.08.2020

Received in revised form 29.09 .2020

Accepted 30.09.2020

Poltava University of Economics and Trade, Koval Str., 3, Poltava, 36014, Ukraine.

Tel.: +38-053-250-02-22

E-mail: can@puet.edu.ua
Boroday, A., Horobes, A., Levchenko, Y., \& Choni, I. (2020). The use of sweet potatoes in the technology of cake dough products. Scientific Messenger of Lviv National University of Veterinary Medicine and Biotechnologies. Series: Food Technologies, 22(94), 13-17. doi: 10.32718/nvlvetf9403

The article highlights the research aimed at proving the prospects of using valuable local raw materials - sweet potatoes to increase the nutritional and biological value, as well as reducing the caloric content of flour products from cake dough. The range of flour confectionery products and the peculiarity of manufacturing technology are analyzed. Cake flour products occupy a significant place in the general structure in terms of production, although the analysis of their physical and chemical composition gives grounds to claim that they do not always have a high degree of nutritional and biological value, balanced chemical composition. This is due to the high proportion of carbohydrates, fats and low content of proteins, vitamins and other biologically active compounds. In addition to nutritional value, the shelf life of products is an important factor. Cake products belong to the fat-containing flour confectionery products, and accordingly they are subjected to oxidative treatment, which encourages the search for new antioxidants of natural origin. The aim of the work is to improve the technology of cake batter with the use of sweet potato puree and to study the influence of additives of local plant raw materials on the structural-mechanical and organoleptic characteristics of finished products. The local raw material of sweet potatoes, which is characterized by a valuable chemical composition as a source of vitamins, micro- and macroelements of pectin and dyes, was chosen as an improver. The main indicators of the quality of sweet potato puree were determined experimentally. The influence of sweet potato puree on the organoleptic characteristics of the finished products was investigated, and it was found that the introduction of $20 \%$ puree by weight of flour is optimal. As the concentration of the puree increases, the taste of the product deteriorates, as well as the porosity decreases and the color changes. The positive effect of sweet potato puree on physico-chemical indicators of the quality of finished products has been established. When adding puree in the amount of $20 \%$ by weight of flour, the porosity is increased by $8 \%$ in comparison with the control sample. The technology of obtaining a cake from sweet potato puree has been developed. The prescription composition and the basic technological scheme of their production are substantiated. It is proved that flour products with the addition of sweet potato puree in the amount of $20 \%$ to the weight of the flour are slower to harden and retain their properties for 9 days of storage. The safety of prolonged storage has been confirmed by microbiological studies. Thus, the expediency of using sweet potato puree in the technology of cake dough products in order to reduce calories, increase the biological value, improve organoleptic characteristics. As well as the possibility of replacing artificial improvers in the structure, taste and aroma of cakes, due to the substances contained in sweet potato puree.

Key words: sweet potatoes, potato culture, sweet potato puree, cake dough products, porosity, organic acids, pectin, fragility.

\section{Використання батату в технології виробів 3 кексового тіста}

\author{
А. Б. Бородай, О. М. Горобець, Ю. В. Левченко, І. В. Чоні
}

Полтавський університет економіки і торгівлі, м. Полтава, Україна

В статті висвітлені дослідження, спрямовані на доведення перспективності використання ијіної місиевої сировини - батату для підвищення харчової та біологічної цінності, а також зниження калорійності борошняних виробів з кексового тіста. Проана- 
лізовано асортимент борошняних кондитерських виробів та особливість технології виготовлення. Кексові борошняні вироби посідають значне місие у загальній структурі за обсягом виробництва, хоча аналіз їх фізико-хімічного складу дає підстави стверджувати, щзо вони не завжди мають високий ступінь поживної та біологічної цінності, збалансований хімічний склад. Це зумовлене високою часткою в їхньому складі вуглеводів, жирів і низьким вмістом - білків, вітамінів та інших біологічно активних сполук. Окрім харчової цінності, важливим фактором є тривалість зберігання виробів. Кексові вироби належать до жировмісних борошняних кондитерських виробів і відповідно вони піддаються окислювальному псуванню, щуо спонукає до пошуків нових антиоксидантів природного походження. Метою роботи є удосконалення технології кексового тіста з використанням пюре батату та дослідження впливу добавок місцевої рослинної сировини на структурно-механічні й органолептичні показники готових виробів. Як поліпшувач була обрана місцева сировина батат, щуо характеризується иінним хімічним складом як джерело вітамінів, мікро-та макроелементів пектинових та барвних речовин. Експерементальним иляхом визначені основні показники якості пюре з батату. Досліджено вплив пюре з пюре батату на органолептичні показники готових виробів, встановлено, шзо оптимальним є внесення $20 \%$ пюре від маси борошна. При збільшенні концентрачії пюре відбувається погіршення смакових якостей виробу, а також знижується пористість та зміюється колір. Встановлено позитивний вплив пюре з батату на фізико-хімічні показники якості готових виробів. При додаванні пюре у кількості 20 \% від маси борошна спостерігається підвищення пористості на 8 \% порівняно з контрольним зразком. Розроблено технологію одержання кексу з пюре батату. Обтрунтовано рецептурний склад і приниипову технологічну схему їх виробництва. Доведено, щзо борошняні вироби з додаванням пюре з батату у кількості 20 \% до маси борошна повільніше піддаються черствінню та зберігають свої властивості протягом 9 діб зберігання. Безпечність пролонгованого зберігання підтверджена мікробіологічними дослідженнями. Отже, встановлено доцільність використання пюре батату в технології виробів з кексового тіста з метою зниження калорійності, підвищення біологічної иінності, поліпшення органолептичних показників, а також можливість заміни штучних поліпшувачів структури, смаку та аромату кексових виробів, за рахунок речовин, які містяться у пюре батату.

Ключові слова: батат, бульбоплідна культура, пюре батату, вироби з кексового тіста, пористість, органічні кислоти, пектинові речовини, крихкість.

\section{Вступ}

У сучасних умовах важливого значення набувають проблеми удосконалення технології виробів поліпшених споживних властивостей, що передбачає зниження енергетичної та підвищення харчової цінності, збагачення складу біологічно активними компонентами, поліпшення органолептичних показників. У зв'язку з цим використання продуктів переробки рослинної сировини (порошків, паст, пюре) у виробництві кондитерських виробів $є$ актуальною проблемою сьогодення (Mazaraki, 2012).

Серед великого різноманіття борошняних кондитерських виробів (БКВ) більшість людей віддають перевагу виробам малої ваги. В цьому випадку тістечка й кекси за популярністю займають одне $з$ перших місць (Mazaraki, 2012).

Борошняні кондитерські вироби містять велику кількість жирів (від 5 до $35 \%$ ) і вуглеводів (від 47 до $100 \%$ ), основну частину яких становлять сахароза й крохмаль, і досить незначну кількість білка (від 3 до $10,5 \%$ ). Їхня енергетична цінність коливається в межах від 350 до 530 ккал на 100 г продукту й залежить, головним чином, від набору рецептурних компонентів (борошна, яєчних і молочних продуктів, різних добавок - горіхів, родзинок, ін.). Істотним недоліком кондитерських виробів є практично повна відсутність у них таких важливих біологічно активних речовин, як вітамінів, харчових волокон, макро- i мікроелементів (Kaprel'janc \& Iorgacheva, 2003; Martynovskyi, \& Somina, 2014).

Подана інформація переконливо свідчить, що кондитерські вироби потребують істотної корекції хімічного складу в напрямку збільшення вмісту вітамінів і мінеральних елементів, харчових волокон при одночасному зниженні енергетичної цінності. Разом із тим у зв'язку зі зростаючим попитом на цю групу продуктів вона може розглядатися як зручний об'єкт для збагачення.

Роботи провідних вітчизняних та закордонних науковців спрямовані на дослідження перспективності використання продуктів переробки рослинної сировини в технології борошняних кондитерських виробів 3 метою збагачення їхного хімічного складу (Zharkova et al., 2011; Correa et al., 2012; Tkachenko, 2013; Khomych, \& Horobets, 2015; 2020). Однак використанню батату 3 цією метою не приділено достатньо уваги, адже батат має цінний хімічний склад, $є$ місцевою сировиною, що доводить актуальність даних досліджень.

Залежно від сорту батат буває білим, жовтим, лимонним, рудим, рожевим, кремовим, червоним, фіолетовим, вишневим, колір свідчить про вміст корисних речовин. Так, рудий - містить багато каротину, а фіолетовий - корисні антоціани (Fu et al., 2016; Wang et al., 2016).

Метою роботи $є$ удосконалення технології кексового тіста 3 використанням пюре батату та дослідження впливу добавок місцевої рослинної сировини на структурно-механічні й органолептичні показники готових виробів.

Для досягнення поставленої мети необхідно вирішити такі завдання:

- визначити показники якості батату;

- визначити вплив пюре батату на фізико-хімічні та органолептичні показники якості готових виробів;

- дослідити показники якості борошняних кексових виробів 3 пюре батату в процесі виробництва і зберігання.

\section{Матеріал і методи досліджень}

Експериментальні дослідження виконувалися на базі науково-дослідних лабораторій кафедри технологій харчових виробництв i ресторанного господарства Полтавського університету економіки i торгівлі.

Якість сировини, що використовувалася у виробництві борошняних кондитерських виробів контролювали за органолептичними, фізико- 
хімічними та мікробіологічними показниками. В роботі використовувалися як загальноприйняті методи (стандартні) досліджень, так і спеціальні або модифіковані. Визначали масову частки вологи в борошні за ДСТУ 21094-75, масову частку сухих речовин у пюре батату за ГОСТ 28562-90, вміст пектинових речовин в сировині $\mathrm{Ca}-$ пектатним методом (Arasimovich et al., 1970), лужність готових виробів за ДСТУ 5024:2008, пористість за ГОСТ 566996. Процес черствіння виробів досліджували впродовж п'ятьох діб за показниками кришкуватості за загальноприйнятими методиками та за зміною вологості виробів (Puchkova, 2004).

\section{Таблиця 1}

Органолептичні показники плодів батату

\section{Результати та їх обговорення}

Для експериментальних досліджень брали батат, зібраний восени 2019 року. Дослідження проводили 3 коренебульбоплодами батату сортів Бетті, Сальса, Мохан, Гарнет, вирощених в центральних районах України, а саме - у Полтавській області.

Органолептична оцінка батату (табл. 1) свідчила про те, що коренебульбоплоди мали помаранчеве забарвлення, смак і слабкий аромат, притаманний даній сировині.

\begin{tabular}{ccccc}
\hline Найменування зразка & Зовнішній вигляд & Колір & Смак & Запах \\
\hline \multirow{2}{*}{ корене-бульбоплоди } & $\begin{array}{c}\text { довжина } 10 \text { см, ширина }-5-6 \mathrm{~cm} \\
\text { майже однакові за розміром }\end{array}$ & \multirow{2}{*}{ помаран-чевий } & \multirow{2}{*}{ специфічний } & $\begin{array}{c}\text { легкий, } \\
\text { специфічний }\end{array}$ \\
\hline
\end{tabular}

За хімічним складом пюре відрізняється від плодів батату. Порівняльна характеристика хімічного складу пюре батату наведена в табл. 2.

\section{Таблиця 2}

Хімічний склад батату та пюре батату

\begin{tabular}{|c|c|c|}
\hline Показники & батат & пюре батату \\
\hline Вода, \% & $63,50 \pm 0,01$ & $60,90 \pm 0,01$ \\
\hline Сухі речовини, \% & $37,50 \pm 0,02$ & $39,10 \pm 0,02$ \\
\hline Білки, \% & $2,50 \pm 0,02$ & $2,20 \pm 0,02$ \\
\hline Вуглеводи, \% & $27,20 \pm 0,03$ & $28,00 \pm 0,03$ \\
\hline $\begin{array}{l}\text { у тому числі пектинові } \\
\text { речовини }\end{array}$ & $0,40 \pm 0,01$ & $1,10 \pm 0,01$ \\
\hline Харчові волокна, \% & $3,60 \pm 0,02$ & $3,60 \pm 0,02$ \\
\hline Каротин мг/100 & $6,00 \pm 0,02$ & $8,00 \pm 0,02$ \\
\hline $\begin{array}{l}\text { L-аскорбінова } \\
\text { мг/100 г }\end{array}$ & $23,00 \pm 0,02$ & $22,00 \pm 0,02$ \\
\hline Зола, \% & $1,40 \pm 0,01$ & $1,30 \pm 0,01$ \\
\hline
\end{tabular}

Дані, наведені в таблиці, доводять, що використання батату дозволить підвищити біологічну цінність кексових виробів за рахунок наявності в сировині пектинових речовин та каротину.

За контрольний зразок була обрана рецептура “Кекс столичний” № 82 згідно зі збірником рецептур (Soboleva, 1985). Дослідні зразки готувалися за класичною технологєю. Пюре батату додавали на стадії приготування тіста у кількості 5 \%, 10 \%, 15 \% від розрахункової маси цукру.

На початкових етапах досліджень визначали вплив пюре 3 батату на структурно-механічні властивості тіста. Особливу увагу приділили зміні в'язкості. Результати досліджень наведено на рисунку 1.

Результати, наведені на діаграмі, демонструють вищі емульгуючі та стабілізуючі властивості тіста 3 добавкою пюре батату, що пов'язано з присутністю в складі добавки значної кількості пектинових речовин та харчових волокон. Так, показник ефективної в'язкості в зразку з додаванням $10 \%$ пюре перевищує показник контролю на $3 \%$, тимчасом як при збільшенні концентрації добавки показник в'язкості знижується. За результатами, неведеними на рисунку, оптимальним $є$ внесення $10 \%$ пюре з батату.

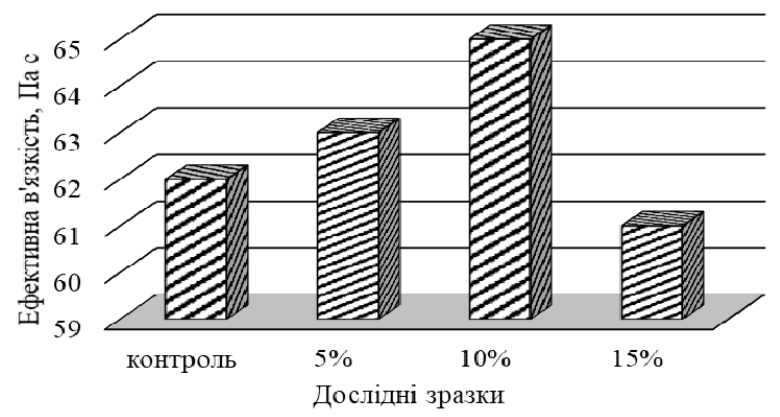

Рис 1. Зміна показника ефективної в'язкості кексового тіста залежно від відсотка внесення пюре з батату

Органолептичну оцінку розроблених виробів проводили за 5-бальною шкалою за такими критеріями: смак, запах, форма, структура, колір скоринки та вигляд на розломі.

Для виробництва кексів з додаванням пюре батату, використовували борошно вищого гатунку 3 вологістю 14,5 \%, цукор-пісок, масло вершкове, яйця, сіль, розпушувач, пюре батату в кількості від 5 до 15 \% від розрахункової маси цукру.

Використання рослинної сировини, а саме пюре батату, забезпечило зміну показників процесу, що впливає на показники якості готових виробів.

Найкращим зразком за результатами оцінки виявився зразок 3, який містить $10 \%$ пюре батату. Встановлено, що контрольні вироби відрізнялися від дослідних світлим м'якушем та нижчою пористістю. Зразок 3 додаванням 10 \% пюре батату мав приємний смак та аромат, гарну пористість, світлопомаранчевий м'якуш.

На основі отриманих оцінок за результатами дегустації були побудовані профілограми (рис. 2). 

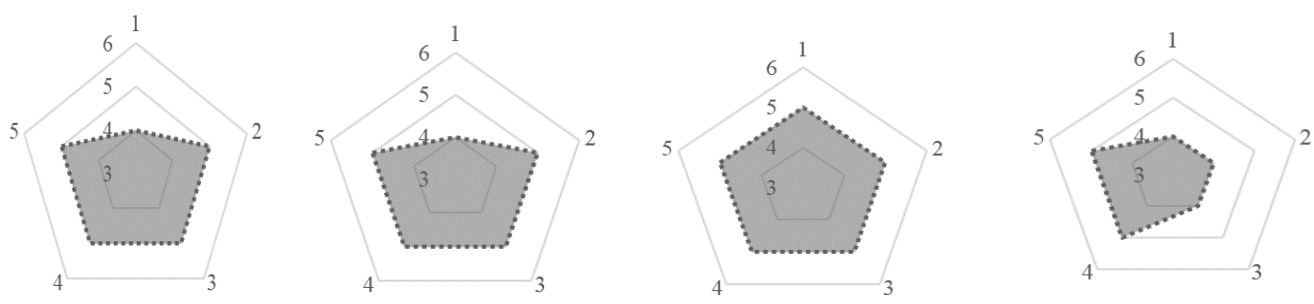

Рис. 2. Профіль органолептичної оцінки кексів із додаванням пюре батату (а) контроль, (б) зразок 5 \% батату , (в) зразок $10 \%$ батату (в) зразок $15 \%$ батату, (в) зразок $40 \%$ батату: 1 - структура та вигляд на зломі, 2 - форма, 3 - аромат, 4 -смак, 5 - колір скоринки

Таким чином, за результатами проведеної органолептичної оцінки якості кексів, виготовлених 3 різним відсотком внесення пюре батату, найкращим виявився зразок із додаванням 10 \% пюре. Далі для грунтовного аналізу було проведено визначення фізико-хімічних показників якості готової продукції, серед яких особливу увагу приділили показникам пористості та питомої ваги. Результати досліджень наведено на рисунку 3.

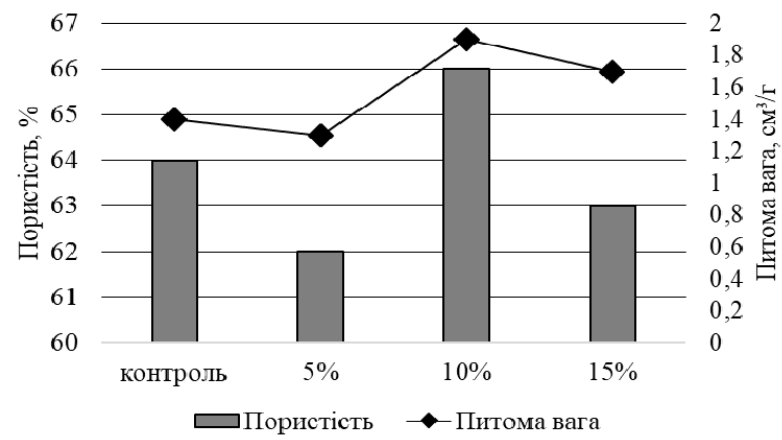

Рис. 3. Зміна показників якості кексів залежно від відсотка внесення пюре з батату.

Дані, показані на рисунку, демонструють позитивний вплив пюре батату на показники якості кексів. Так, при додаванні $10 \%$ пюре 3 батату показник пористості підвищується на $8 \%$, а питома вага на $35 \%$ порівняно 3 контрольним зразком. Отримані дані пояснюються вмістом в добавці харчових волокон, які мають здатність стабілізувати емульсію, а також утримувати більшу кількість вологи. Підвищення пористості поліпшує засвоєння виробу.

Поряд з умістом пектинових речовин та харчових волокон пюре батату характеризується достатнім вмістом каротину, вітамінів $\mathrm{E}$ та $\mathrm{C}$, які володіють антиоксидантними властивостями, що дає змогу припустити, що додавання батату впливатиме на процес окиснення жиру та тривалість зберігання. Для підтвердження висунутої гіпотези провели дослідження 3 визначення впливу батату на кислотне число жиру та на зміну вологості виробів під час зберігання протягом 12 діб. Результати досліджень наведено на рисунку 4.

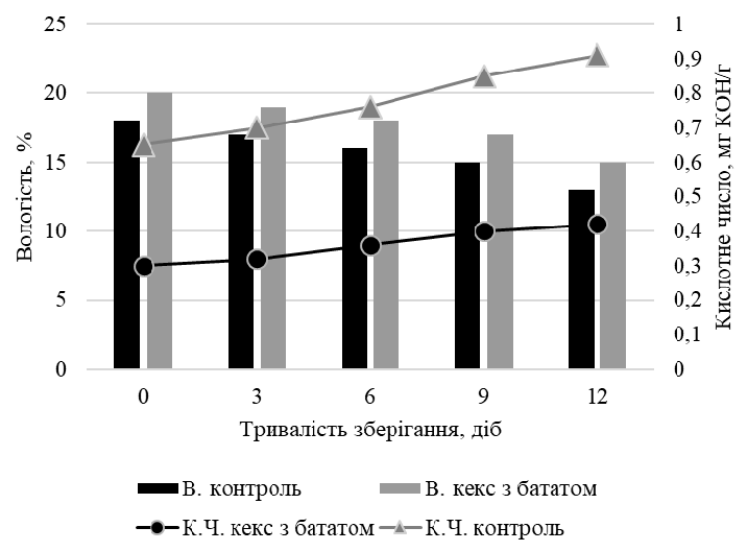

Рис. 4. Зміна вологості та кислотного числа під час зберігання

За нормативною документацією тривалість зберігання кексів на хімічних розпушувачах без добавок складає 7 діб. Виявлено, що через 12 діб зберігання кислотне число зразка з додаванням пюре батату має нижчий показник, ніж в контрольному зразку. Відомо, що якщо жир не містить достатньої кількості жирних кислот з кількістю атомів вуглецю менше ніж 8, то його смак та запах внаслідок гідролізу або не змінюється, або змінюється несуттєво. Основні жирні кислоти жирів кексу (маргарину) та пюре батату містять не менше ніж 14 атомів вуглецю (пальмітинова С16:0, стеаринова $\mathrm{C} 18: 0$, олеїнова $\mathrm{C} 18: 1$ і лінолева C18:2), тому протікання гідролітичних процесів є незначним. Тобто і через 12 днів зберігання, коли в дослідних зразках з'являються органолептичні ознаки прогірклого жиру, їх кислотне число не перевищує значення 2 мг КОН/г, яке встановлене нормативними документами.

Гальмування процесу окиснення жиру пояснюється високими антиоксидантними властивостями пюре 3 батату за рахунок його хімічного складу.

Окрім того, зразок $з$ додаванням пюре 3 батату повільніше піддається черствінню, що зумовлено гідратаційними властивостями добавки.

Для підтвердження безпечності подовженого терміну зберігання 3 огляду на мікробіологічні показники були проведені мікробіологічні дослідження та вставлено, що ступінь мікробіологічного забруднення протягом всього терміну зберігання перебуває в межах допустимих 
норм.

Таким чином, дослідження змін фізико-хімічних показників якості кексів під час зберігання показали, що додавання пюре батату дозволить отримати виріб, який і через 12 діб за всіма показниками відповідає вимогам документів, котрі регламентують його якість.

\section{Висновки}

Результати проведених досліджень свідчать про можливість заміни $10 \%$ традиційно використовуваного у технології борошняних кондитерських виробів цукру на пюре батату із забезпеченням якості виробів за всіма нормативними показниками відповідно до нормативної документації. Використання батату у виробництві кексів $\epsilon$ доцільним 3 огляду на збагачення продукту біологічно цінними білковими компонентами, вітамінами й мікроелементами, що містяться в даній сировинні, а саме каротинами та харчовими волокнами. Додавання пюре батату в кількості $10 \%$ від розрахункової маси цукру дозволяе підвищити пористість виробів на $8 \%$, а також подовжити тривалість зберігання до 12 діб. Безпечність пролонгованого зберігання підтверджена мікробіологічними дослідженнями.

Перспективи подальших досліджень. Подальші дослідження спрямовані на визначення можливості заміни частини жиру на пюре батату 3 метою зниження калорійності даного виду борошняних виробів, а також можливість використання батату в інших видах тіста.

\section{References}

Arasimovich, V. V., Baltaga, S. V., \& Panomareva, N. P. (1970). Metody analiza pektinovyh veshhestv, gemiceljuloz i pektoliticheskih fermentov $\mathrm{v}$ ploda. Kishenev: RIO AN MSSR (in Russian).

Correa, M. J., Perez, G. T., \& Ferrero, C. (2012). Pectins as breadmaking additives: effect on dough rheology and bread quality. Food and Bioprocess Technology, 5(7), 2889-2898. doi: 10.1007/s11947-011-0631-6.

Fu, Z. F., Tu, Z. C., Zhang, L., Wang, H., Wen, Q. H., \& Huang, T. (2016). Antioxidant activities and polyphenols of sweet potato (Ipomoea batatas L.) leaves extracted with solvents of various polarities. Food Bioscience, 15, 11-18. doi: 10.1016/j.fbio.2016.04.004.

Kaprel'janc, L. V., \& Iorgacheva, K. G. (2003). Funkcional'nye produkty: monografija. Odessa: Druk (in Russian).

Khomych, H. P., \& Horobets, O. M. (2015). Vykorystannia khenomelesu ta produktiv yoho pererobky v tekhnolohii boroshnianykh vyrobiv. Naukovyi visnyk Lvivskoho natsionalnoho universytetu veterynarnoi medytsyny ta biotekhnolohii imeni S. Z. Gzhytskoho, 17(4), 174-179. URL: http://nbuv.gov.ua/UJRN/nvlnu_2015_17_4_33 (in Ukrainian).

Khomych, H. P., \& Horobets, O. M. (2020). Kompleksne vykorystannia zhuravlyny $\mathrm{v}$ tekhnolohii boroshnianykh vyrobiv. Naukovyi visnyk PUET: Technical Sciences, 1(91), 25-32. doi: 10.37734/2518-7171-2019-1-4 (in Ukrainian).

Martynovskyi, V. S., \& Somina, Yu. O. (2014). Suchasnyi stan i perspektyvy rozvytku kondyterskoi haluzi Ukrainy. Ekonomika kharchovoi promyslovosti, 2, 43-45. URL: http://nbuv.gov.ua/UJRN/echp_2014_2_12 (in Ukrainian).

Mazaraki, A. A. (2012). Tekhnolohiia produktiv funktsionalnoho pryznachennia: monohrafiia. K.: Kyiv. nats. torh.-ekon. un-t (in Ukrainian).

Puchkova, L. I. (2004). Laboratornyj praktikum po tehnologii muchnyh konditerskih izdelij. 4-oe izd., pererab. i dop. SPb.: GIORD (in Russian).

Soboleva, Z. T. (1985). Sbornik receptur muchnyh konditerskih i bulochnyh izdelij dlja predprijatij obshhestvennogo pitanija. M.: Jekonomika. M-vo togovli SSSR (in Russian).

Tkachenko, A. S. (2013). Poshuky shliakhiv znyzhennia enerhetychnoi tsinnosti boroshnianykh kondyterskykh vyrobiv. Naukovyi visnyk Poltavskoho universytetu ekonomiky i torhivli. Seriia “Tekhnichni nauky”, 1(57), 94-96. URL: http://journal.puet.edu.ua/index.php/nvts/ article/view/975 (in Ukrainian).

Wang, S., Nie, S., \& Zhu, F. (2016). Chemical constituents and health effects of sweet potato. Food Research International, 89, 90-116. doi: 10.1016/j.foodres.2016.08.032.

Zharkova, I., Maljutina, T., \& Ahtemirov, E. (2011). Netradicionnoe rastitel'noe syr'e $\mathrm{v}$ tehnologii keksov. Hleboprodukty, 8, 40-42 (in Russian). 